\title{
Ultralyd ved temporalisarteritt
}
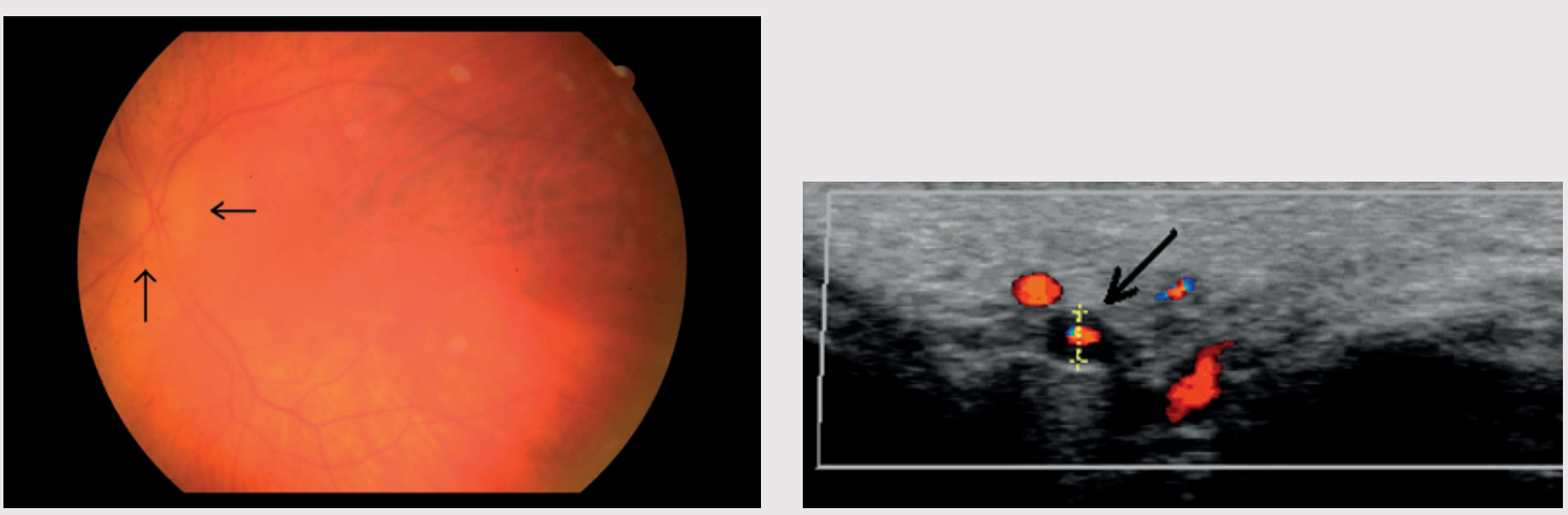

En 87 år gammel kvinne med kjent bilateral carotisstenose, hypertensjon og hjertesvikt hadde i flere uker smerter over begge tinninger, spesielt mens hun spiste. Utover dette hadde hun ikke hodepine. Hun ble henvist øyeavdeling med mistanke om netthinneløsning etter at hun akutt mistet synet på venstre øye. Undersøkelse viste papillødem, peripapillær blødning og iskemisk preg langs arkadene nedenfor macula på venstre side (forenlig med mulig temporalisarteritt) (bildet til venstre) (piler) og velavgrenset papill på høyre side (bilde kun i Tidsskriftets nettutgave).

Pasienten ble innlagt i Nevrologisk avdeling med mistanke om sentralarterieokklusjon eller temporalisarteritt. Nevrologisk undersøkelse var upåfallende, med unntak av visustap venstre side. Pasienten hadde ikke hodepine. Temporalisarterien var verken hoven eller trykkøm, CRP var $19 \mathrm{mg} / 1$ (referanseverdi $<5 \mathrm{mg} / \mathrm{l}$ ) og senkningsreaksjonen var $25 \mathrm{~mm} / \mathrm{t}$ (referanseverdi $<30 \mathrm{~mm} / \mathrm{t}$ ). Ultralydundersøkelse av temporalarterien viste hypoekkoisk halo i arterieveggen som tegn på veggødem (bildet til høyre). Biopsi viste kjempeceller samt inflammatoriske forandringer $i$ og rundt arterieveggen (bilde kun i Tidsskriftets nettutgave) og bekreftet diagnosen temporalisarteritt.
Pasienten ble behandlet med prednisolon. CRP sank til 3,3 mg/l og senkningsreaksjonen til $10 \mathrm{~mm} / \mathrm{t}$. Smertene forsvant, og synet på høyre side kunne bevares. Nytteverdien av ultralydundersøkelse ved spørsmål om temporalisarteritt er omdiskutert, men den var nyttig i dette tilfellet, da det var uvanlige kliniske tegn med lav CRP, lav senkning samt fravær av hodepine.

\section{Sara Maria Wörlund}

sara.woerlund@sus.no

Nevrologisk avdeling

og

Nasjonalt kompetansesenter

for bevegelsesforstyrrelser

Janne Kristine Bethuelsen

Patologisk avdeling

\section{Sumit Roy}

Radiologisk avdeling

\section{Oddbjørn Bjordal}

$\emptyset$ yeavdelingen

Stavanger universitetssjukehus

\section{Martin Kurz}

Nevrologisk avdeling

og

Nasjonalt kompetansesenter

for bevegelsesforstyrrelser

Stavanger universitetssjukehus
Pasienten har gitt tillatelse til at artikkelen blir publisert.

To e-bilder finnes kun i Tidsskriftets nettutgave.

Sara Maria Wörlund (f. 1979) er assistentlege ved Nevrologisk avdeling.

Ingen oppgitte interessekonflikter.

Janne Kristine Bethuelsen (f. 1976) er lege i spesialisering ved Avdeling for patologi. Ingen oppgitte interessekonflikter.

Sumit Roy (f. 1960) er dr.philos., radiolog og overlege ved Seksjon for intervensjonsradiologi, Avdeling for radiologi.

Ingen oppgitte interessekonflikter.

Oddbjørn Bjordal (f. 1980) er lege. Ingen oppgitte interessekonflikter.

Martin W. Kurz (f. 1975), er ph.d., spesialist i nevrologi og seksjonsoverlege ved slagpost. Oppgitte interessekonflikter: Forfatteren har mottatt foredragshonorar fra Pfizer og Boeringer-Ingelheim.

Manus mottatt 1.6. 2011, første revisjon innsendt 8.7. 2011, godkjent 15.9. 2011. Medisinsk redaktør Erlend T. Aasheim. 